\title{
Molecular understanding of the suppression of new-particle formation by isoprene
}

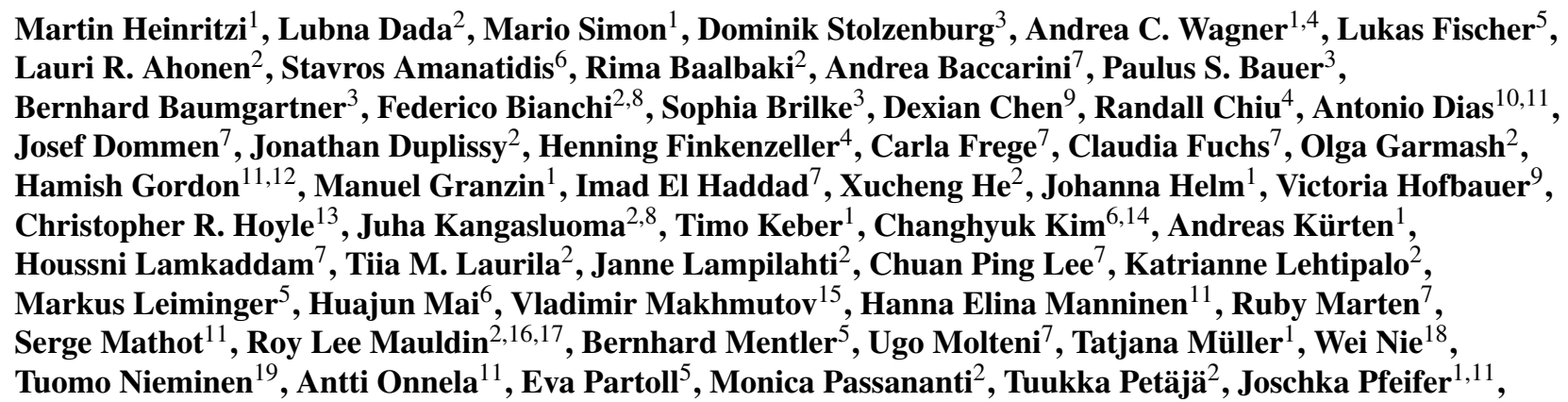
Veronika Pospisilova ${ }^{7}$, Lauriane L. J. Quéléver ${ }^{2}$, Matti P. Rissanen ${ }^{2}$, Clémence Rose ${ }^{2,20}$, Siegfried Schobesberger ${ }^{19}$, Wiebke Scholz ${ }^{5}$, Kay Scholze ${ }^{3}$, Mikko Sipilä ${ }^{2}$, Gerhard Steiner ${ }^{5}$, Yuri Stozhkov ${ }^{15}$, Christian Tauber ${ }^{3}$, Yee Jun Tham ${ }^{2}$, Miguel Vazquez-Pufleau ${ }^{3}$, Annele Virtanen ${ }^{19}$, Alexander L. Vogel ${ }^{1,11}$, Rainer Volkamer ${ }^{4}$, Robert Wagner ${ }^{2}$, Mingyi Wang ${ }^{9}$, Lena Weitz ${ }^{1}$, Daniela Wimmer ${ }^{2}$, Mao Xiao ${ }^{7}$, Chao Yan $^{2}$, Penglin Ye ${ }^{9,21}$, Qiaozhi Zha ${ }^{2}$, Xueqin Zhou $^{1,7}$, Antonio Amorim ${ }^{10}$, Urs Baltensperger ${ }^{7}$, Armin Hansel ${ }^{5}$, Markku Kulmala ${ }^{2,8,22}$, António Tomé23, Paul M. Winkler ${ }^{3}$, Douglas R. Worsnop ${ }^{2,21}$, Neil M. Donahue ${ }^{9}$, Jasper Kirkby ${ }^{1,11}$, and Joachim Curtius ${ }^{1}$

${ }^{1}$ Institute for Atmospheric and Environmental Sciences, Goethe University Frankfurt, 60438 Frankfurt am Main, Germany

${ }^{2}$ Institute for Atmospheric and Earth System Research (INAR)/Physics, Faculty of Science,

University of Helsinki, 00014 Helsinki, Finland

${ }^{3}$ Faculty of Physics, University of Vienna, 1090 Vienna, Austria

${ }^{4}$ Department of Chemistry \& CIRES, University of Colorado at Boulder, Boulder, CO 80309-0215, USA

${ }^{5}$ Institute for Ion and Applied Physics, University of Innsbruck, 6020 Innsbruck, Austria

${ }^{6}$ California Institute of Technology, Pasadena, CA 91125, USA

${ }^{7}$ Laboratory of Atmospheric Chemistry, Paul Scherrer Institute, 5232 Villigen, Switzerland

${ }^{8}$ Aerosol and Haze Laboratory, Beijing Advanced Innovation Center for Soft Matter Science and Engineering,

Beijing University of Chemical Technology, Beijing, 100029, China

${ }^{9}$ Center for Atmospheric Particle Studies, Carnegie Mellon University, Pittsburgh, PA 15213, USA

${ }^{10}$ CENTRA and FCUL, University of Lisbon, 1749-016 Lisbon, Portugal

${ }^{11}$ CERN, 1211 Geneva, Switzerland

${ }^{12}$ School of Earth and Environment, University of Leeds, Leeds, LS 9JT, UK

${ }^{13}$ Institute for Atmospheric and Climate Science, ETH Zurich, Zurich, Switzerland

${ }^{14}$ Department of Environmental Engineering, Pusan National University, Busan 46241, Republic of Korea

${ }^{15}$ Lebedev Physical Institute, Russian Academy of Sciences, 119991, Moscow, Russia

${ }^{16}$ Department of Atmospheric and Oceanic Sciences, University of Colorado at Boulder, Boulder, CO 80309, USA

${ }^{17}$ Department of Chemistry, Carnegie Mellon University, Pittsburgh, PA 15213, USA

${ }^{18}$ Joint International Research Laboratory of Atmospheric and Earth System Sciences, School of Atmospheric Sciences, Nanjing University, Nanjing, 210023, China

${ }^{19}$ Department of Applied Physics, University of Eastern Finland, P.O. Box 1627, 70211 Kuopio, Finland

${ }^{20}$ Laboratory for physical meteorology, UMR6016, University Clermont Auvergne-CNRS, 63178, Aubière, France

${ }^{21}$ Aerodyne Research, Inc., Billerica, MA 01821, USA

${ }^{22}$ Helsinki Institute of Physics, University of Helsinki, 00014 Helsinki, Finland

${ }^{23}$ IDL-University of Beira Interior, Covilhã, Portugal 
Correspondence: Joachim Curtius (curtius@iau.uni-frankfurt.de)

Received: 19 January 2020 - Discussion started: 17 February 2020

Revised: 13 July 2020 - Accepted: 14 August 2020 - Published: 20 October 2020

\begin{abstract}
Nucleation of atmospheric vapours produces more than half of global cloud condensation nuclei and so has an important influence on climate. Recent studies show that monoterpene $\left(\mathrm{C}_{10} \mathrm{H}_{16}\right)$ oxidation yields highly oxygenated products that can nucleate with or without sulfuric acid. Monoterpenes are emitted mainly by trees, frequently together with isoprene $\left(\mathrm{C}_{5} \mathrm{H}_{8}\right)$, which has the highest global emission of all organic vapours. Previous studies have shown that isoprene suppresses new-particle formation from monoterpenes, but the cause of this suppression is under debate. Here, in experiments performed under atmospheric conditions in the CERN CLOUD chamber, we show that isoprene reduces the yield of highly oxygenated dimers with 19 or 20 carbon atoms - which drive particle nucleation and early growth - while increasing the production of dimers with 14 or 15 carbon atoms. The dimers (termed $\mathrm{C}_{20}$ and $\mathrm{C}_{15}$, respectively) are produced by termination reactions between pairs of peroxy radicals $\left(\mathrm{RO}_{2} \bullet\right.$ ) arising from monoterpenes or isoprene. Compared with pure monoterpene conditions, isoprene reduces nucleation rates at $1.7 \mathrm{~nm}$ (depending on the isoprene / monoterpene ratio) and approximately halves particle growth rates between 1.3 and $3.2 \mathrm{~nm}$. However, above $3.2 \mathrm{~nm}, \mathrm{C}_{15}$ dimers contribute to secondary organic aerosol, and the growth rates are unaffected by isoprene. We further show that increased hydroxyl $\operatorname{radical}(\mathrm{OH} \bullet)$ reduces particle formation in our chemical system rather than enhances it as previously proposed, since it increases isoprene-derived $\mathrm{RO}_{2} \cdot$ radicals that reduce $\mathrm{C}_{20}$ formation. $\mathrm{RO}_{2}$ • termination emerges as the critical step that determines the highly oxygenated organic molecule (HOM) distribution and the corresponding nucleation capability. Species that reduce the $\mathrm{C}_{20}$ yield, such as $\mathrm{NO}, \mathrm{HO}_{2}$ and as we show isoprene, can thus effectively reduce biogenic nucleation and early growth. Therefore the formation rate of organic aerosol in a particular region of the atmosphere under study will vary according to the precise ambient conditions.
\end{abstract}

\section{Introduction}

Nucleation of aerosol particles is observed in many environments, ranging from boreal forests to urban and coastal areas, from polar to tropical regions, and from the boundary layer to the free troposphere (Kerminen et al., 2018). Gaseous sulfuric acid, ammonia (Kirkby et al., 2011), amines (Almeida et al., 2013) and, in coastal regions, iodine (Sipilä et al., 2016) were shown to contribute to nucleation. Additionally, a small fraction of the large pool of organic molecules in the atmosphere, namely highly oxygenated organic molecules (HOMs), some of which possess extremely low vapour pressures, nucleate together with other precursors as well as on their own (Riccobono et al., 2014; Kirkby et al., 2016; Tröstl et al., 2016). This means nature is nucleating particles on a large scale without pollution, and this may have been especially pervasive in the pre-industrial atmosphere (Gordon et al., 2016). HOMs can be formed with molar yields in the single-digit percent range from the oxidation of monoterpenes $\left(\mathrm{C}_{10} \mathrm{H}_{16}\right)$ with endocyclic $\mathrm{C}=\mathrm{C}$ double bonds (Kirkby et al., 2016; Ehn et al., 2014). Monoterpenes are emitted by a variety of trees in regions ranging from the tropics to northern latitudes, often reaching mixing ratios of tens to hundreds of parts per trillion by volume (pptv) (Jardine et al., 2015; Guenther et al., 2012). Isoprene is a hemiterpene $\left(\mathrm{C}_{5} \mathrm{H}_{8}\right)$ emitted by broadleaf trees and has the highest emissions of any biogenic organic compound, with concentrations reaching several parts per billion by volume (ppbv) in the Amazon rainforest and the southeastern United States despite high reactivity (Guenther et al., 2012; Martin et al., 2010; Lee et al., 2016). Numerous studies report suppression of nucleation in isoprene-rich environments, even if sufficient monoterpenes are present (Lee et al., 2016; Kanawade et al., 2011; Yu et al., 2014; Kiendler-Scharr et al., 2009, 2012; Varanda Rizzo et al., 2018; Wimmer et al., 2018). This isoprene suppression effect has been demonstrated in carefully controlled chamber studies (Kiendler-Scharr et al., 2009, 2012) and observed in isoprene-rich ambient locations (Kanawade et al., 2011; Lee et al., 2016; Yu et al., 2014). A recent study also reported a suppression of secondary organic aerosol (SOA) formation due to isoprene in an $\mathrm{OH} \cdot$-dominated chamber experiment (McFiggans et al., 2019). In addition to observing suppression of particle formation by isoprene, earlier studies have proposed mechanisms to explain it. One possibility is $\mathrm{OH}$ • depletion by isoprene, which would reduce the oxidation rate of monoterpenes and thus supersaturation driving nucleation (Kiendler-Scharr et al., 2009, 2012; McFiggans et al., 2019). However, $\mathrm{OH} \cdot$ is observed to remain high and undisturbed in isoprene-rich environments due to atmospheric $\mathrm{OH} \cdot$ recycling mechanisms triggered by isoprene (Taraborrelli et al., 2012; Martinez et al., 2010; Fuchs et al., 2013). Further it was shown that ozonolysis is crucial for HOM formation (Ehn et al., 2014; Kirkby et al., 2016). Another proposed possibility for isoprene suppression of nucleation is the deactivation of sulfuric acid cluster growth due to the addition of isoprene oxidation products (Lee et al., 2016). However, HOMs can nucleate without sulfuric acid (Kirkby et al., 2016), and sup- 
pression of nucleation by isoprene is observed in pristine environments such as the Amazon (Martin et al., 2010).

Isoprene oxidation by $\mathrm{OH} \cdot$ triggers complex peroxyradical chemistry with a variety of products such as hydroxy-hydroperoxides (ISOPOOH), hydroperoxyaldehydes (HPALD) and second-generation low-volatility compounds (Teng et al., 2017; Berndt et al., 2016). Isoprene oxidation products with low volatility such as dihydroxyepoxides (IEPOX) contribute to secondary organic aerosol formation (Carlton et al., 2009; Krechmer et al., 2015; Paulot et al., 2009; Surratt et al., 2010; Lin et al., 2011; Budisulistiorini et al., 2013). Recently, the interaction of isoprene and monoterpene oxidation chemistry was studied, and it was found that isoprene-derived $\mathrm{RO}_{2}$ molecules can reduce the formation of monoterpene-derived dimers (Berndt et al., 2018b; McFiggans et al., 2019). However, the effect of this interaction on nucleation and early growth of particles under atmospherically relevant conditions remains unclear so far. One consequence of this is an over-prediction of cloud condensation nuclei $(\mathrm{CCN})$ in the Amazon by models that simulate pure biogenic nucleation but neglect the role of isoprene in new-particle formation (Gordon et al., 2016).

Here, we present experiments performed under atmospherically relevant conditions at the CERN CLOUD chamber and show on a molecular level how isoprene affects the chemistry of monoterpene oxidation, thus reducing nucleation rates as well as early growth rates.

\section{Methods}

The Cosmics Leaving Outdoor Droplets (CLOUD) chamber at the European Center for Nuclear Research (CERN) is a $26.1 \mathrm{~m}^{3}$ stainless-steel aerosol chamber, in which a large variety of atmospheric conditions can be recreated under precisely controlled conditions (Kirkby et al., 2011, 2016; Duplissy et al., 2016). The chamber is thermally insulated, and its temperature can be precisely controlled in the range from -65 to $100^{\circ} \mathrm{C}$. In order to reduce contaminations, air mixed from cryogenic nitrogen and oxygen is used. Trace gases like $\alpha$-pinene and isoprene can be added and controlled via a twostage dilution system at the parts per trillion by volume level. Mixing is ensured by two magnetically coupled fans. The chamber is equipped with a UV excimer laser and $\mathrm{Hg}-\mathrm{Xe}$ UV lamps in order to trigger photochemistry. Ion-free conditions can be generated by applying a high voltage electric field across the chamber that sweeps out naturally produced ions (neutral conditions). When this field is switched off, ions produced by galactic cosmic rays (gcr's) penetrating the chamber are allowed to stay inside the chamber, and their effect on nucleation processes can be studied. Using the CERN $\pi^{+}$-beam increases the ion concentration artificially (see Supplement for more detail).
The air inside the chamber is continuously analysed by a variety of instruments. Organic precursors ( $\alpha$-pinene and isoprene) are measured by a PTR3 instrument (Breitenlechner et al., 2017). HOMs are measured by a nitrate chemicalionization atmospheric-pressure-interface time-of-flight (CIAPI-TOF) mass spectrometer (Kürten et al., 2011) that is connected to the chamber via a $1^{\prime \prime}$ core sampling probe, where only the inner part of the flow is sampled into the ion source of the instrument in order to minimise wall losses. Number concentration and size distribution of newly formed particles are measured with an array of butanol-based condensation particle counters (CPCs), diethylene-glycol-based particle size magnifiers (PSMs), and a differential mobility analyser (DMA) train and a scanning mobility particle sizer (SMPS) (see Supplement for more detail).

A typical experiment starts with the injection of $\alpha$-pinene into the particle-free chamber (see Figs. S1 and S2 in the Supplement), while other parameters like temperature, humidity and ozone levels are already stabilised. Oxidation of $\alpha$-pinene by both $\mathrm{O}_{3}$ and $\mathrm{OH}$ leads to the formation of HOMs, which subsequently lead to the formation of particles. The experiment is continued without intervention until a steady state in HOMs and nucleation rate has been established. Once the nucleation and growth rates have been determined, the next experiment is performed under slightly different conditions. Parameters that were varied are $\alpha$-pinene and isoprene levels, ion concentration, UV illumination, sulfuric acid concentration, temperature and relative humidity.

\section{Results}

We performed several experiments at +5 and $+25^{\circ} \mathrm{C}$ and relative humidity $(\mathrm{RH})$ ranging from $20 \%$ to $80 \%$ with most of the experiments being carried out at $38 \% \mathrm{RH}$. Ozone levels ranged from 30 to $50 \mathrm{ppbv}$. We directly compare experiments performed with $\alpha$-pinene as the sole biogenic vapour to experiments with a mixture of $\alpha$-pinene and isoprene. $\alpha$ Pinene levels ranged from 0.33 to $2.5 \mathrm{ppbv}$, while isoprene levels ranged from 2.5 to 10 ppbv. We thus could recreate conditions similar to Kirkby et al. (2016), as well as to regions like the Amazon (Martin et al., 2010; Yáñez-Serrano et al., 2018) and southeastern parts of the United States (Lee et al., 2016).

Ozone attack on the endocyclic $\alpha$-pinene $\mathrm{C}=\mathrm{C}$ double bond leads to the well-described formation of highly oxygenated $\mathrm{RO}_{2}$ - radicals via intramolecular $\mathrm{H}$ shift and autoxidation (mainly $\mathrm{C}_{10} \mathrm{H}_{15} \mathrm{O}_{4,6,8,10}$, from now on referred to as $\left.\mathrm{RO}_{2}(\alpha \mathrm{p})\right)$ as well as a wide spectrum of closed-shell monomers (mainly $\mathrm{C}_{10} \mathrm{H}_{14,16} \mathrm{O}_{5,7,9,11}$ ) and covalently bound dimers (mainly $\mathrm{C}_{20} \mathrm{H}_{30} \mathrm{O}_{8-16}$ and $\mathrm{C}_{19} \mathrm{H}_{28} \mathrm{O}_{7-11}$; see Fig. 1a) (Ehn et al., 2014; Kirkby et al., 2016; Rissanen et al., 2015; Berndt et al., 2018b; Molteni et al., 2019). These highly oxygenated organic molecules (HOMs) nucleate at atmospherically relevant concentrations with the help of ions but 


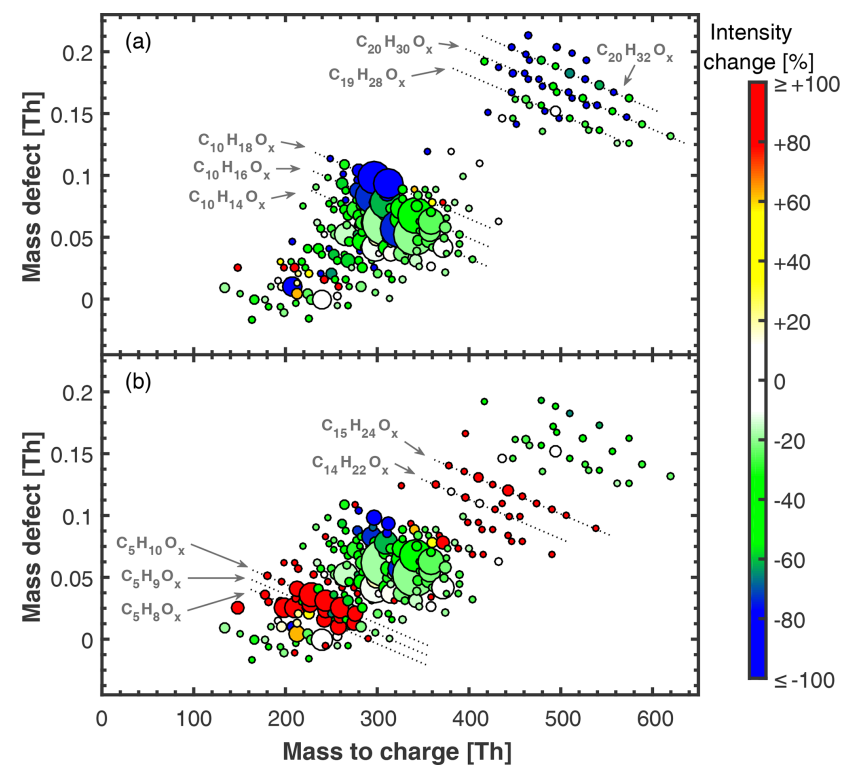

Figure 1. Mass defect plots of neutral HOM molecules measured with nitrate CI-API-TOF without isoprene (a) and with isoprene added (b) at $+25^{\circ}$ C. $\alpha$-Pinene levels were 771 and 1326 pptv, respectively. Ozone levels were 49 and 39 ppbv, respectively. Isoprene was 4.9 ppbv in (b). Relative humidity was $38 \%$ in (a) and (b). The area of the marker points is linearly scaled with the intensity of the HOM signals. Colour code shows the relative intensity change for each HOM peak due to isoprene addition, i.e. the percentage intensity change between (a) and (b). The colour for each peak is thus the same in (a) and (b). HOM intensity in (a) was scaled up linearly by $38 \%$ to match $\left[\alpha\right.$-pinene] $\left[\mathrm{O}_{3}\right]$ levels present in (b) to calculate the intensity change.

without other species (e.g. sulfuric acid or bases) required (Kirkby et al., 2016). Here, we group the HOMs according to carbon atom number and define $\mathrm{C}_{5}, \mathrm{C}_{10}, \mathrm{C}_{15}$ and $\mathrm{C}_{20}$ classes as the sum of all HOMs with 2-5, 6-10, 11-15 and 16-20 carbon atoms, respectively. This resembles the basic building block unit of a $\mathrm{C}_{5}$ isoprenoid skeleton.

An isoprene-ozone mixture in the CLOUD chamber produces $\mathrm{C}_{5} \mathrm{H}_{9} \mathrm{O}_{5-9} \mathrm{RO}_{2} \cdot$ radicals (referred to as $\mathrm{RO}_{2}$ (ip)) which terminate to $\mathrm{C}_{5} \mathrm{H}_{8} \mathrm{O}_{5-8}$ and $\mathrm{C}_{5} \mathrm{H}_{10} \mathrm{O}_{5-9}$ monomers and also some $\mathrm{C}_{10} \mathrm{H}_{18} \mathrm{O}_{8-10}$ dimers under UV-illuminated conditions (see Fig. S5a, b). The $\mathrm{C}_{5} \mathrm{H}_{9} \mathrm{O}_{5-9}$ radicals originate presumably from an $\mathrm{OH} \cdot$ addition to isoprene and subsequent autoxidation. Under dark conditions, when the only source of $\mathrm{OH} \cdot$ is isoprene ozonolysis at $26 \%$ yield (Malkin et al., 2010), we observe only $\mathrm{C}_{5}$ monomers. None of these molecules are able to nucleate under atmospherically relevant conditions despite having an oxygen-to-carbon ratio $(\mathrm{O}: \mathrm{C}) \geq 1$, which agrees with earlier observations that products from isoprene ozonolysis do not drive significant newparticle formation (Kamens et al., 1982; Riva et al., 2017).

When isoprene is present together with $\alpha$-pinene and ozone, the HOM chemistry of $\alpha$-pinene is altered. We observe the appearance of $\mathrm{C}_{15}$ and an increase in $\mathrm{C}_{5}$ class molecules compared to $\alpha$-pinene-only conditions as well as a decrease in $\mathrm{C}_{20}$ and $\mathrm{C}_{10}$ class molecules (see Figs. 1 and $\mathrm{S} 3$ ). Without isoprene, $\mathrm{RO}_{2}(\alpha \mathrm{p})$ can terminate with another $\mathrm{RO}_{2}(\alpha \mathrm{p})$, thus forming either one $\mathrm{C}_{20}$ dimer or two $\mathrm{C}_{10}$ monomers. Monomers can also be formed by termination with $\mathrm{HO}_{2}$ or unimolecular termination (Rissanen et al., 2015). The presence of $\mathrm{RO}_{2}$ (ip) offers additional termination channels (Berndt et al., 2018a) (see Fig. 2) and acts as an additional loss term for $\mathrm{RO}_{2}(\alpha \mathrm{p})$. Reactions between $\mathrm{RO}_{2}$ (ip) and $\mathrm{RO}_{2}(\alpha \mathrm{p})$ are expected to result in $\mathrm{C}_{5}$ and $\mathrm{C}_{10}$ monomers as well as $\mathrm{C}_{15}$ dimers. Most importantly, the reduced $\mathrm{RO}_{2}(\alpha \mathrm{p})$ steady-state concentrations lead to a reduction of $\mathrm{C}_{20}$ class dimers by roughly $50 \%$ (depending on detailed conditions) compared to their level in the absence of isoprene for all studied $\alpha$-pinene concentrations (see Fig. S3). To our knowledge the only study that presented ambient measurements of HOMs for an isoprene-rich region is from the SOAS campaign (Southern Oxidant and Aerosol Study, Alabama, USA) (Massoli et al., 2018). When comparing our results with this study, we find good qualitative agreement for the distribution of HOMs with strong contributions in the $\mathrm{C}_{5}$ and $\mathrm{C}_{10}$ region and lesser contributions in the $\mathrm{C}_{15}$ and $\mathrm{C}_{20}$ region. We have to caution however that the $\mathrm{C}_{15}$ signal in the reported HOM distribution could also be caused by sesquiterpene products. Additionally, the presence of $\mathrm{NO}_{x}$ affects $\mathrm{HOM}$ chemistry in Alabama, which also leads to $\mathrm{C}_{20}$ reduction (Lehtipalo et al., 2018).

We measured the particle formation rate directly at a $1.7 \mathrm{~nm}$ cut-off diameter with a scanning particle size magnifier (PSM) under neutral (high-voltage field cage switched on; see Supplement for details) and ion conditions (highvoltage field cage switched off, allowing for galactic cosmic ray (gcr) ionisation in the chamber), further referred to as $J_{\mathrm{n}}$ and $J_{\mathrm{gcr}}$ (see Supplement for detail). Figure $3 \mathrm{a}$ shows $J_{\mathrm{n}}$ and $J_{\text {gcr }}$ plotted against the total HOM concentration (the sum of the $\mathrm{C}_{5}, \mathrm{C}_{10}, \mathrm{C}_{15}$ and $\mathrm{C}_{20}$ classes) for the $\alpha$-pinene-only case and $\alpha$-pinene + isoprene. For $+5^{\circ} \mathrm{C}$ we find good agreement with Kirkby et al. (2016). However, the presence of isoprene and the consequent change in oxidation chemistry reduce $J_{\mathrm{gcr}}$ by a factor of 2 to 4 and $J_{\mathrm{n}}$ even more by around 1 order of magnitude at $5{ }^{\circ} \mathrm{C}$. The suppression is stronger for lower $\alpha$-pinene concentrations and thus higher values of $R$ (the ratio of isoprene to monoterpene carbon).

The larger gap between $J_{\mathrm{gcr}}$ and $J_{\mathrm{n}}$ with isoprene present compared to $\alpha$-pinene-only conditions is direct evidence that isoprene oxidation products destabilise the nucleating clusters, thus making cluster stabilisation through the presence of charge more efficient. This also confirms that $\mathrm{C}_{20}$ class molecules are mainly responsible for pure biogenic nucleation (Frege et al., 2018). $\mathrm{C}_{15}$ class molecules, which tend to counteract the losses of the $\mathrm{C}_{20}$ class, do not prevent a decrease in $J$. Earlier studies have already suggested that $\mathrm{C}_{10}$ class molecules do not possess low enough vapour pressure to qualify as extremely low-volatility organic compounds (Kurtén et al., 2016; Tröstl et al., 2016) and thus do not drive 


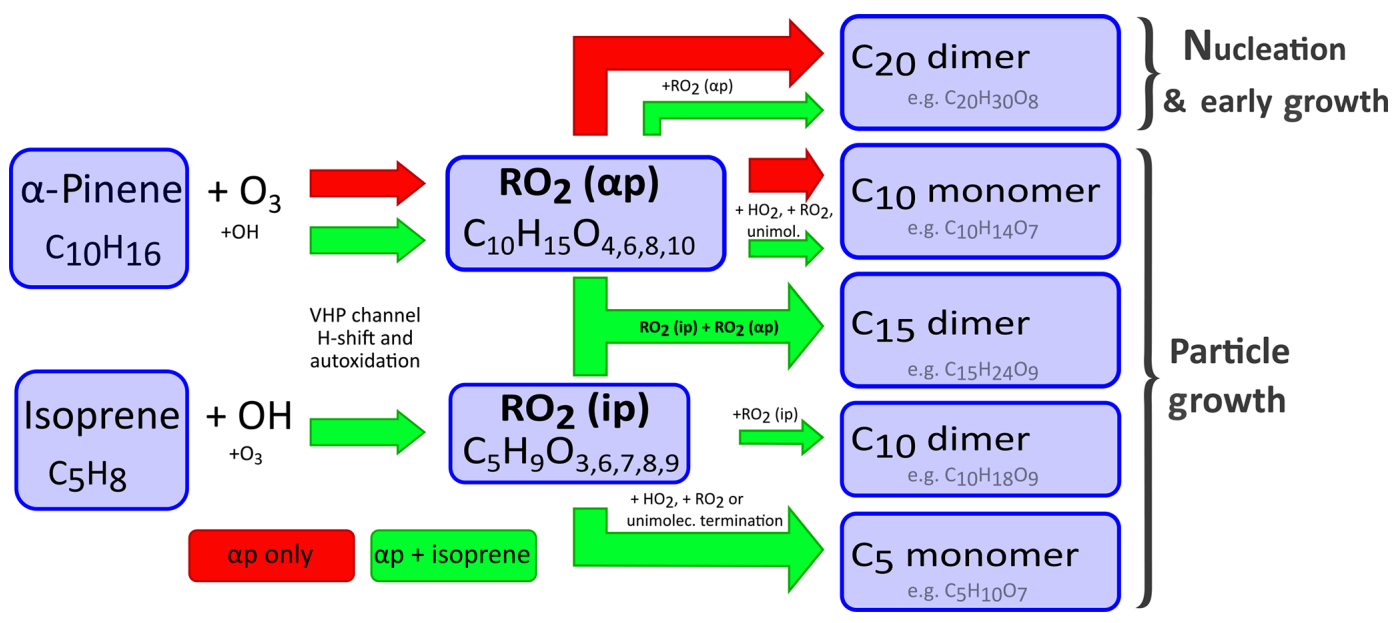

Figure 2. Proposed mechanism for the interference of isoprene in $\alpha$-pinene oxidation chemistry. The pathway of HOM formation of an $\alpha$-pinene-ozone mixture alone is indicated by red arrows. When isoprene is present, the green arrows indicate the additional interference of isoprene in $\alpha$-pinene oxidation chemistry via $\mathrm{RO}_{2} \cdot$ radicals. The oxidation of $\alpha$-pinene in the conditions used in our experiments is dominated by ozonolysis. After the initial ozone attack a $\mathrm{C}_{10} \mathrm{H}_{15} \mathrm{O}_{4}$, peroxy radical forms via a vinylhydroperoxide channel (VHP), which can undergo various intramolecular $\mathrm{H}$ shifts and autoxidation steps. Thus the chain of $\mathrm{RO}_{2}(\alpha \mathrm{p})$ mostly consists of $\mathrm{C}_{10} \mathrm{H}_{15} \mathrm{O}_{4,6,8,10}$. These radicals can terminate either via reaction with other $\mathrm{RO}_{2}$ - radicals, via reaction with $\mathrm{HO}_{2}$ or via unimolecular processes. The resulting closed-shell products are then either covalently bound $\mathrm{C}_{20}$ class dimers, which are mostly responsible for nucleation, or $\mathrm{C}_{10}$ class monomers. Possible fragmentation might also lead to a low number of $\mathrm{C}_{5}$ and $\mathrm{C}_{15}$ class molecules being formed even without isoprene present. Isoprene oxidation is dominated by reactions with $\mathrm{OH} \bullet$ in the CLOUD chamber, which produce a series of $\mathrm{C}_{5} \mathrm{RO}_{2} \bullet \operatorname{radicals}\left(\mathrm{C}_{5} \mathrm{H}_{9} \mathrm{O}_{3,6,7,8,9}\right)$. These $\mathrm{RO}_{2}$ (ip) radicals can now interfere in the termination of $\mathrm{RO}_{2}(\alpha \mathrm{p})$. The reaction of $\mathrm{RO}_{2}$ (ip) with $\mathrm{RO}_{2}(\alpha \mathrm{p})$ can lead to $\mathrm{C}_{15}$ class dimers, $\mathrm{C}_{10}$ class monomers or $\mathrm{C}_{5}$ class monomers. The reaction of $\mathrm{RO}_{2}$ (ip) with another $\mathrm{RO}_{2}$ (ip) can lead to $\mathrm{C}_{10}$ class dimers or $\mathrm{C}_{5}$ class monomers. The presence of $\mathrm{RO}_{2}(\mathrm{ip})$ reduces the steady-state concentration of $\mathrm{RO}_{2}(\alpha \mathrm{p})$, as it acts as an additional sink for $\mathrm{RO}_{2}(\alpha \mathrm{p})$. This directly reduces the formation of $\mathrm{C}_{20}$ class dimers, as two $\mathrm{RO}_{2}(\alpha \mathrm{p})$ radicals are needed to form one $\mathrm{C}_{20}$ class dimer. We link this reduction of $\mathrm{C}_{20}$ class dimers to the reduction of biogenic nucleation and early growth rates in the presence of isoprene.

nucleation, leaving $\mathrm{C}_{20}$ class molecules as the most likely nucleator molecules. At $+25^{\circ} \mathrm{C}$ and $\mathrm{UV}$ light illumination, we find that nucleation rates of the pure $\alpha$-pinene system are reduced by a factor of about $2-3$ compared to $+5^{\circ} \mathrm{C}$. This is a much smaller reduction in nucleation rate compared to, e.g. the inorganic sulfuric acid water system, for which the same temperature increase reduces nucleation rates by around 2 orders of magnitude (Kirkby et al., 2011) due to an increase in vapour pressure at warmer temperatures. In our organic system, however, accelerated oxidation chemistry counters the effect of higher vapour pressures. This includes a higher rate of initial oxidation of $\alpha$-pinene by ozone, as well as a faster autoxidation process, which leads to HOMs with generally higher oxygen content. When we add isoprene at $+25^{\circ} \mathrm{C}$ with a constant ratio of isoprene to monoterpene carbon $(R=2)$, we find a reduction in $J_{\mathrm{gcr}}$ of around a factor of about 2 . Similar to the data at $+5^{\circ} \mathrm{C}$ where $R$ ranges from 1.6 to 6.5 , we expect a stronger decrease for higher values of $R$. This can be understood as higher isoprene concentrations enhance $\mathrm{RO}_{2}$ (ip) formation, which in turn reduces $\mathrm{C}_{20}$ production and subsequent nucleation. $R$ can reach levels around 15 in the Amazon (Greenberg et al., 2004) and around 26 in Michigan (Kanawade et al., 2011), where we would thus expect an even stronger isoprene effect on nucleation.
Comparing HOM formation and nucleation for three different $\alpha$-pinene and isoprene settings, we observe that the addition of $2.7 \mathrm{ppbv}$ of isoprene to an $\alpha$-pinene-ozone mixture (770 pptv and $49 \mathrm{ppbv}$, respectively) mitigates $\mathrm{C}_{20}$ production and reduces $J_{1.7}$ from 3.2 to $0.81 \mathrm{~cm}^{-3} \mathrm{~s}^{-1}$ (see Fig. S6). A rough doubling of both the $\alpha$-pinene and isoprene levels to $1326 \mathrm{pptv}$ and $4.87 \mathrm{ppbv}$, respectively, increases overall $\mathrm{HOM}$ production; however, $\mathrm{C}_{20}$ levels and consequently $J_{1.7}$ remain lower than in the original pure $\alpha$-pinene setting without isoprene. Thus even increasing monoterpene concentrations can lead to lower $J$ values when isoprene is added as well. Additional evidence for the important role of $\mathrm{C}_{20}$ is shown in Fig. S9. Regressing each individual HOM peak with $J_{\mathrm{gcr}}$ gives high coefficients of determination for $\mathrm{C}_{20}$ class molecules.

It has been argued that $\mathrm{OH} \cdot$ depletion by isoprene is responsible for the absence of nucleation in isoprene-rich environments (Kiendler-Scharr et al., 2009, 2012); however, under atmospheric conditions, isoprene-induced $\mathrm{OH} \cdot$ recycling can lead to undisturbed high $\mathrm{OH} \cdot$ levels, which might not be true in chamber experiments (Taraborrelli et al., 2012; Martinez et al., 2010; Fuchs et al., 2013). In our study we also see an $\mathrm{OH} \cdot$ depletion effect due to isoprene addition (see Fig. S1 and Supplement for detailed discussion). However, 

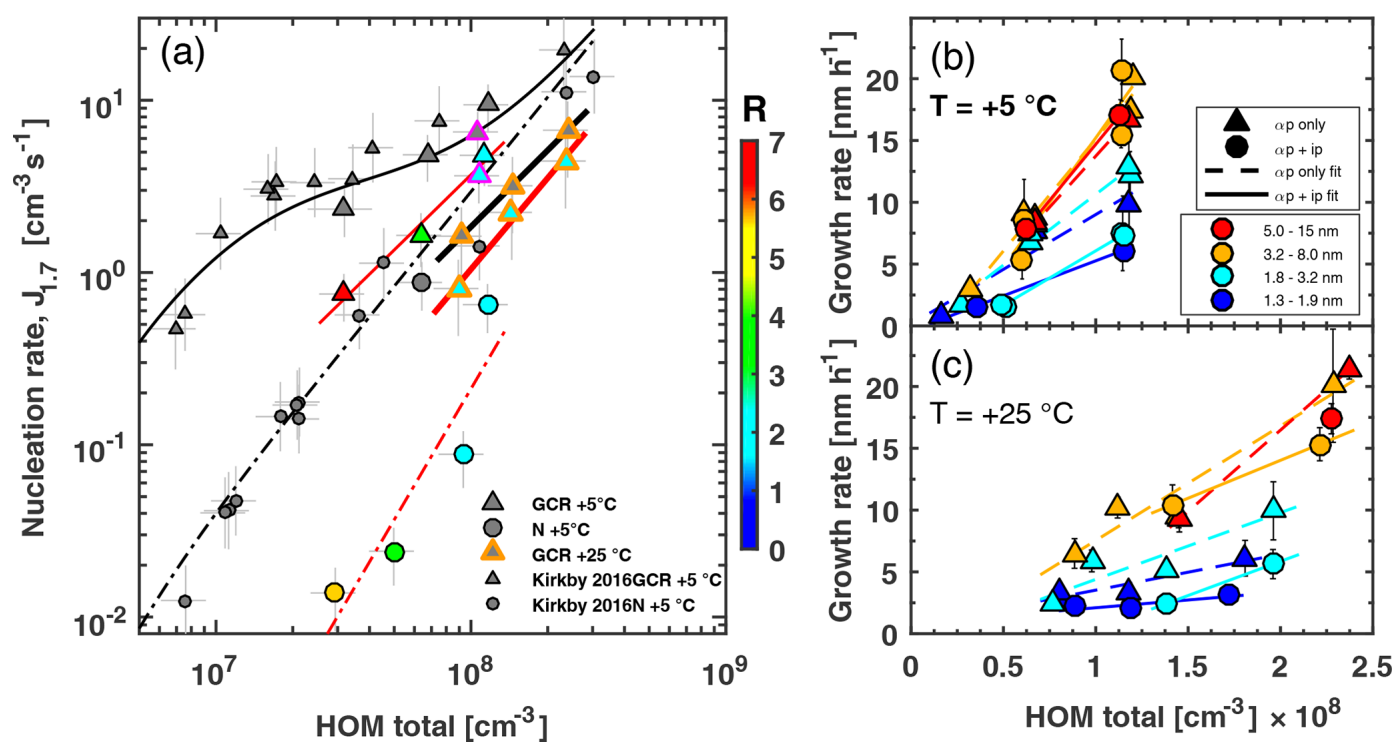

Figure 3. Pure biogenic nucleation rates at $1.7 \mathrm{~nm}$ diameter (a) and growth rates (b, c) against total HOM concentration with and without isoprene added at +5 and $+25^{\circ} \mathrm{C}$. $\mathrm{HOM}$ total is defined as the sum of $\mathrm{C}_{5}, \mathrm{C}_{10}, \mathrm{C}_{15}$ and $\mathrm{C}_{20}$ carbon classes. Relative humidity is $38 \%$ for all data points. (a) Triangles represent $J_{\text {gcr }}$ and circles $J_{\mathrm{n}}$. Small grey points were taken from Kirkby et al. (2016). Magenta edges indicate UV-illuminated conditions at $+5^{\circ} \mathrm{C}$; at $+25^{\circ} \mathrm{C}$ all data points are with UV light on. Colour shows isoprene-to-monoterpene carbon ratio $(R)$. Black solid and dashed-dotted lines are parameterisations of $J_{\mathrm{gcr}}$ and $J_{\mathrm{n}}$ from Kirkby et al. (2016). Red solid and dashed-dotted lines are power-law fits to $J_{\mathrm{gcr}}$ and $J_{\mathrm{n}}$ in the presence of isoprene at $+5^{\circ} \mathrm{C}$. Thick solid black and red lines represent power-law fits to $+25^{\circ} \mathrm{C}$ data for $\alpha$-pinene only and $\alpha$-pinene + isoprene systems. Bars indicate $1 \sigma$ run-to-run uncertainty. The overall systematic scale uncertainty of HOMs of $+78 \%$ and $-68 \%$ and of $J$ for $\pm 47 \%$ is not shown. In (b) and (c), triangles represent $\alpha$-pinene only and circles represent $\alpha$-pinene + isoprene conditions. Marker colour indicates the size range in which growth rate was measured: dark blue $1.3-1.9 \mathrm{~nm}$ (measured by scanning PSM), light blue 1.8-3.2 nm, orange 3.2-8.0 nm (both measured by DMA train) and red 5.0-15 nm (measured by nano-SMPS). Bars indicate $1 \sigma$ uncertainties in growth rate estimation. Dashed lines are linear fits to $\alpha$-pinene-only data points; solid lines are linear fits to $\alpha$-pinene + isoprene conditions.

if $\mathrm{OH} \cdot$ depletion were the reason for suppression of nucleation, an increase in $\mathrm{OH} \cdot$ would lead to an increase in the nucleation rate. When we increase $\mathrm{OH} \cdot$ levels by switching on UV lights in the presence of isoprene, this reduces $\mathrm{RO}_{2}(\alpha \mathrm{p})$ further, as well as the $\mathrm{C}_{20}$ and $\mathrm{C}_{10}$ class molecules, while enhancing the $\mathrm{C}_{5}$ and $\mathrm{C}_{15}$ classes (see Figs. S1, S4 and S5c, $\mathrm{d}$ as well as the Supplement for details). Accordingly, $J$ is also reduced slightly instead of being increased. In the atmosphere with considerable $\mathrm{OH} \cdot$ recycling, this effect, and therefore the suppression of new-particle formation, would be even stronger. We can understand this $\mathrm{OH} \cdot$ effect by comparing the reactivity of $\alpha$-pinene and isoprene towards $\mathrm{OH} \cdot$ at our given concentrations. For 300 and $1200 \mathrm{pptv}$ the reactivity of $\alpha$-pinene towards $\mathrm{OH} \cdot$ at $+5^{\circ} \mathrm{C}\left([\alpha \mathrm{p}] \cdot k_{\alpha \mathrm{pOH}}\right)$ is 25.1 and 6.3 times lower, respectively, than the reactivity of $4 \mathrm{ppbv}$ isoprene towards $\mathrm{OH} \cdot\left([\mathrm{ip}] \cdot k_{\mathrm{ipOH}}\right)$. At $+25^{\circ} \mathrm{C}$ these numbers are similar (25.4 and 6.3, respectively). This implies that any additional $\mathrm{OH} \cdot$ provided by UV illumination will favour the formation of additional $\mathrm{RO}_{2}$ (ip) instead of $\mathrm{RO}_{2}(\alpha \mathrm{p})$, thus favouring the formation of $\mathrm{C}_{15}$ over $\mathrm{C}_{20}$ and consequently reducing nucleation rates. $\mathrm{OH} \cdot$ does not enhance nucleation in this chemical system; it suppresses it.
We performed experiments at $+25^{\circ} \mathrm{C}$ with three different levels of relative humidity $(20 \%, 38 \%$ and $80 \%)$ to probe the effect of water on new-particle formation. Changes in humidity do not significantly affect HOM formation and $J_{\text {gcr }}$ (see Fig. S7). $J_{\mathrm{n}}$ increased slightly with humidity, showing an increased stabilisation of nucleating clusters by water; however, in ger conditions, this role is fulfilled more efficiently by ions.

We further studied the effect of sulfuric acid on nucleation of an $\alpha$-pinene-isoprene mixture (about $1300 \mathrm{pptv}$ and $4.5 \mathrm{ppbv}$, respectively) in experiments with excess ammonia $(0.4-2.5 \mathrm{ppbv})$ in order to reproduce typical conditions in the eastern parts of the United States (Lee et al., 2016). We find that sulfuric acid does not enhance biogenic nucleation up to a concentration of $5 \times 10^{6} \mathrm{~cm}^{-3}$ (see Fig. S8). This decoupling of biogenic nucleation from low sulfuric acid levels is similar to the pure $\alpha$-pinene system reported in Kirkby et al. (2016). At sulfuric acid levels higher than $5 \times 10^{6} \mathrm{~cm}^{-3}$, nucleation rates depend strongly on sulfuric acid levels, which agrees with a wide variety of atmospheric measurements (Kirkby et al., 2016). In the Amazon, sulfuric acid levels are typically in the range of $1-5 \times 10^{5} \mathrm{~cm}^{-3}$ (Kanawade et al., 2011), well below the threshold value of 
$5 \times 10^{6} \mathrm{~cm}^{-3}$. In Alabama this threshold was exceeded only three times in a $45 \mathrm{~d}$ measurement period due to transported sulfur plumes, which led to two events of particles growing to larger sizes (Lee et al., 2016). In Michigan, sulfuric acid concentrations are typically in the range of $1 \times 10^{6} \mathrm{~cm}^{-3}$ (Kanawade et al., 2011). Sulfuric acid is thus not an important contributor to nucleation in the Amazon as well as different regions of the eastern United States.

We measured the growth rates of freshly nucleated particles from $1.3 \mathrm{~nm}$ onwards with a scanning particle size magnifier, a DMA train and a nano-SMPS (see Supplement for details). The change in HOM chemistry caused by concurrent isoprene oxidation reduces the growth rates of particles in the range of 1.3-1.9 and 1.8-3.2 nm roughly by a factor of 2 (Fig. 3b, c). This confirms that $\mathrm{C}_{15}$ class molecules have a higher saturation vapour pressure than $\mathrm{C}_{20}$ class molecules and are thus less efficient than $\mathrm{C}_{20}$ class molecules at causing growth of the smallest particles. Likewise, most $\mathrm{C}_{10}$ class molecules are too volatile to contribute significantly to the early stages of growth (Tröstl et al., 2016). For the size range from 3.2 to $8.0 \mathrm{~nm}$ and larger, we observed no suppression effect due to isoprene, indicating that molecules smaller than $\mathrm{C}_{20}$ are capable of condensing onto larger particles. We find a linear relationship of growth rate vs. $\mathrm{C}_{20}$ for 1.3-1.9 and 1.8$3.2 \mathrm{~nm}$, regardless of isoprene presence. For larger sizes the linear relationship is independent of isoprene presence, when plotted against $\mathrm{C}_{15}+\mathrm{C}_{20}$; this again indicates that $\mathrm{C}_{15}$ contributes to growth at larger sizes (Fig. S10). Besides $\mathrm{C}_{15}$ and $\mathrm{C}_{20}$, however, even lighter and less oxygenated molecules can contribute to particle growth at larger sizes (Stolzenburg et al., 2018). Growth rates at $+25^{\circ} \mathrm{C}$ are typically halved compared to $+5^{\circ} \mathrm{C}$ due to higher saturation vapour pressure of the HOMs (Stolzenburg et al., 2018), which leads to a higher chance of particles being scavenged while growing, even more so in the presence of isoprene.

Figure 4 shows the formation rate of particles measured at diameters of 1.7, 2.2, 2.5 and $6 \mathrm{~nm}$ for gcr conditions and six concentration values (low, middle and high $\alpha$-pinene mixing ratios with and without isoprene) at $+25^{\circ} \mathrm{C}$. We find that due to the reduced growth rates in the presence of isoprene, a moderate reduction of formation rates at $1.7 \mathrm{~nm}$ becomes much more pronounced, while the particles grow to larger sizes. When we compare $\alpha$-pinene-only data (771 pptv $\alpha$-pinene, 49 ppbv $\mathrm{O}_{3}$ ) with a mixture (1320 pptv $\alpha$-pinene, $39 \mathrm{ppbv} \mathrm{O}_{3}$ and $4.9 \mathrm{ppbv}$ isoprene, orange data points in Fig. 4$), J_{1.7}$ is reduced by $45 \%$, while the corresponding formation rate at $6 \mathrm{~nm}$ is reduced by an order of magnitude. The corresponding precursor concentrations are similar to conditions found in Alabama for example (Lee et al., 2016). Isoprene can thus drastically reduce the formation of particles larger than $6 \mathrm{~nm}$ even at relatively warm temperatures like $+25^{\circ} \mathrm{C}$. This growth-rate-driven effect becomes stronger when $\alpha$-pinene concentrations are reduced. Our measurements agree with observations of small clusters that are unable to grow efficiently, as has been reported for

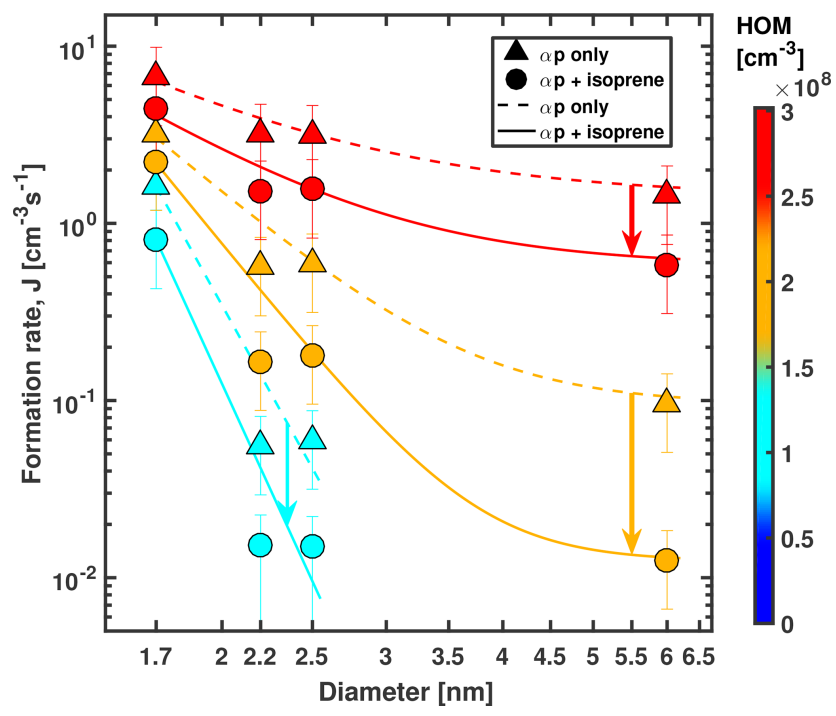

Figure 4. Formation rate (gcr) vs. diameter of particles at $+25^{\circ} \mathrm{C}$ and $38 \% \mathrm{RH}$. Triangles represent $\alpha$-pinene only, and circles represent $\alpha$-pinene + isoprene conditions. $\alpha$-Pinene levels were 456, 771 and 1442 pptv for triangles and 677, 1326 and 2636 pptv for circles. Ozone levels were $49 \mathrm{ppbv}$ for triangles and 38 to $40 \mathrm{ppbv}$ for circles. Isoprene levels ranged from 2.7 to $9.8 \mathrm{ppbv}$ for circles. Colour code represents HOM concentration. Bars indicate overall scale uncertainty for formation rates of $\pm 47 \%$. The uncertainty in the diameters is $\pm 0.3 \mathrm{~nm}$. Dashed and solid lines are lines to guide the eye. The steeper slope at lower-diameter values is caused by the Kelvin effect, i.e. a smaller growth rate at small sizes that leads to higher losses of newly formed particles. The formation rate measurements at 2.2 and $2.5 \mathrm{~nm}$ for the lowest $\alpha$-pinene-isoprene setting (cyan circles) are upper limits.

Alabama (Lee et al., 2016) and the Amazon (Wimmer et al., 2018). Increased levels of pre-existing aerosols (i.e. condensation sink) can scavenge freshly nucleated particles (Dada et al., 2017); however, due to the reduced initial growth rates, the likelihood for that process at a given condensation sink is increased when isoprene is present compared to $\alpha$-pineneonly conditions.

\section{Discussion}

Pure biogenic nucleation was first described for $\alpha$-pinene oxidation in the CLOUD chamber (Kirkby et al., 2016). Global evaluation of this process with the help of atmospheric modelling found an over-prediction of CCN concentrations in the Amazon, leading to speculation about an as yet unaccountedfor chemical suppression mechanism for new-particle formation involving isoprene (Gordon et al., 2016). With our findings, we provide the molecular understanding for such a mechanism and identify $\mathrm{C}_{20}$ class molecules as the main drivers of biogenic nucleation and early growth. This allows us to refine our understanding of biogenic nucleation for isoprene-rich regions, while at the same time large por- 
tions of the atmosphere where biogenic nucleation is very important remain unaffected by our findings, especially boreal forests (Gordon et al., 2016).

Suppression of new-particle formation by isoprene was previously attributed to competition for $\mathrm{OH} \bullet$ radicals during the initial oxidation of volatile organic compounds (VOCs), which was then thought to be followed by independent oxidation pathways (Kiendler-Scharr et al., 2009). Instead we show that the suppression takes place via $\mathrm{RO}_{2} \cdot$ radical interactions that strongly couple the oxidation chains of monoterpenes and isoprene.

McFiggans et al. (2019) showed that the same $\mathrm{RO}_{2} \bullet$ mechanism that we describe here is also responsible for reduced SOA formation, together with an additional $\mathrm{OH} \cdot$ scavenging effect. The oxidation chemistry in McFiggans et al. (2019) was dominated $(>90 \%)$ by $\mathrm{OH} \cdot$ for both monoterpenes and isoprene. In our experimental conditions, monoterpene oxidation was dominated by ozone, which is more common in the atmosphere, and we demonstrate the importance of the $\mathrm{RO}_{2} \cdot$ mechanism directly in these conditions. Additionally, while the precursor concentrations in McFiggans et al. (2019) were much higher than typical atmospheric levels, the precursor levels in the current study resemble the atmosphere more closely. This is especially important as HOM formation is not a linear process and can thus not be scaled down to atmospheric levels in a straightforward manner.

All extrapolations of chamber experiments to atmospheric conditions must be treated with care; for example, it has been shown that isoprene $\mathrm{OH} \cdot$ scavenging is stronger in common chamber conditions than in ambient conditions, where $\mathrm{OH}$ • recycling (e.g. by HPALD photolysis) counters the $\mathrm{OH} \cdot$ consumption by isoprene (Taraborrelli et al., 2012).

McFiggans et al. (2019) also show that $\mathrm{OH} \cdot$ scavenging by isoprene is important for reduced SOA formation. We also find a reduction in $\mathrm{OH} \cdot$ levels due to isoprene addition in the CLOUD chamber. However, this is not the reason for the suppression of nucleation and early growth rates in our experiments. Quite to the contrary, the dominant effect of increased $\mathrm{OH} \bullet$ in our experiments is to increase $\mathrm{RO}_{2}$ (ip) due to the fast reaction between isoprene and $\mathrm{OH} \bullet ; \mathrm{OH} \bullet$ thus suppresses $\mathrm{C}_{20}$ dimers and nucleation rates in our chemical system. Thus, while increased $\mathrm{OH} \cdot$ levels restore SOA formation partially in the coupled monoterpene-isoprene system, as shown by McFiggans et al. (2019), they suppress nucleation in our experiments. This further highlights the important differences between SOA formation with pre-existing seed particles on the one hand and the nucleation of new particles on the other hand. SOA mass production and nucleation are not the same thing. SOA formation with preexisting particles can include molecules possessing comparatively high saturation vapour pressures; however, due to the Kelvin effect (Tröstl et al., 2016), nucleation depends critically on molecules with extremely low saturation vapour pressure. Most of the $\mathrm{C}_{20}$ and $\mathrm{C}_{15}$, many of the $\mathrm{C}_{10}$, and some of the $\mathrm{C}_{5}$ products can form SOA mass, whereas nucle- ation under atmospheric conditions is driven largely by the $\mathrm{C}_{20}$ dimers. Even replacing $\mathrm{C}_{20}$ with $\mathrm{C}_{15}$ dimers suppresses nucleation, as shown in this study.

Our findings are significant beyond the $\alpha$-pinene-isoprene system, as they indicate the interaction of a variety of atmospheric VOCs with monoterpene-derived HOM formation and new-particle formation. Given that $\mathrm{RO}_{2}(\alpha \mathrm{p})$ and $\mathrm{RO}_{2}$ (VOC) reaction rates are competitive (see Supplement for details), VOCs whose $\mathrm{RO}_{2}$ - radicals lead to products that are smaller than $\mathrm{C}_{20}$ when reacting with $\mathrm{RO}_{2}(\alpha \mathrm{p})$ (i.e. reduce the ELVOC (extremely low-volatility organic compounds) fraction in the HOM distribution) are expected to reduce biogenic nucleation and early growth. On the other hand, VOCs that lead to $\mathrm{C}_{20}$ class or larger molecules are expected to accelerate both processes. $\mathrm{RO}_{2}$ - termination emerges as the critical step in ELVOC formation and subsequently biogenic newparticle formation. The suppression of biogenic new-particle formation by isoprene and potentially other lighter VOCs, $\mathrm{NO}_{x}$ (Lehtipalo et al., 2018) and elevated $\mathrm{HO}_{2}$ concentrations proceeds along the same lines of $\mathrm{RO}_{2}$ - termination and subsequent $\mathrm{C}_{20}$ reduction, highlighting the importance of $\mathrm{C}_{20}$ class molecules for biogenic new-particle formation.

In summary, we find that isoprene interferes with $\alpha$-pinene $\mathrm{HOM}$ chemistry via $\mathrm{RO}_{2} \cdot$ peroxy-radical termination. When isoprene is present, fewer $\mathrm{C}_{20}$ class molecules are formed, which directly reduces the nucleation rate. We show that $\mathrm{C}_{20}$ class molecules act as "nucleator" species. The reduction of nucleation rate becomes stronger with higher isoprene-tomonoterpene carbon ratio $(R)$, consistent with earlier observations (Kiendler-Scharr et al., 2009); however, in the monoterpene-isoprene chemical system, increased $\mathrm{OH} \cdot$ does not enhance nucleation, but, on the contrary, reduces it due to $\mathrm{C}_{20}$ class reduction. Biogenic nucleation in the $\alpha$-pineneisoprene system is not affected by typical concentrations of sulfuric acid found in the Amazon or in eastern parts of the United States. The change in monoterpene HOM chemistry due to isoprene reduces organic growth rates in the $1.3-3.2 \mathrm{~nm}$ range by around $50 \%$, which strongly reduces the probability that the smallest, freshly nucleated particles will survive scavenging as they grow to larger sizes. While other factors can also inhibit nucleation (e.g. $\mathrm{NO}_{x}$, Wildt et al., 2014, or a high condensation sink, Dada et al., 2017), isoprene can make the difference between measurable newparticle formation events and their absence under a variety of atmospheric conditions.

Data availability. Data are available by contacting the corresponding author.

Supplement. The supplement related to this article is available online at: https://doi.org/10.5194/acp-20-11809-2020-supplement. 
Author contributions. MH, LD, MaS, DS, ACW, LF, LRA, SA, FB, $\mathrm{SB}, \mathrm{RB}, \mathrm{RC}, \mathrm{AD}$, JonD, IEH, HF, CaF, ClF, HG, MG, XH, JH, VH, CK, TK, AK, JuK, ML, KL, TML, JL, CPL, HL, HM, UM, SM, VM, BM, RLM, TM, RM, HEM, WN, AO, TP, VP, JP, LLJQ, MPR, YS, WS, SS, KS, GS, MiS, YJT, RV, ALV, AV, MVP, MW, LW, DW, RW, MX, PY, CY, QZ, XZ, JaK and AT prepared the CLOUD facility and measurement instruments. MH, LD, MaS, DS, ACW, LF, LRA, SA, FB, AB, SB, PSB, BB, RB, DC, RC, AD, JonD, IEH, HF, ClF, HG, OG, MG, XH, JH, CRH, VH, CK, TK, KL, JL, CPL, HL, UM, VM, BM, RLM, TM, RM, HEM, TN, WN, JP, MoP, LLJQ, MPR, CR, YS, WS, SS, KS, GS, CT, YJT, RV, AV, MVP, LW, DW, MX, PY, CY, QZ, XZ, JaK, AA and AT collected the data. MH, LD, MaS, DS, LF, HF, VH, JuK, BM, TN, EP, GS, RV, MX and CY analyzed the data. MH, LD, MaS, DS, ACW, LF, JonD, HG, AK, KL, RLM, MPR, MiS, ALV, PY, CY, NMD, JaK, UB, PMW, JC, DRW, AH and MK contributed to the scientific discussion. $\mathrm{MH}$, LD, MaS, DS, ACW, AK, NMD, JaK, UB and JC contributed to writing the manuscript.

Competing interests. The authors declare that they have no conflict of interest.

Acknowledgements. We thank CERN for supporting CLOUD with technical and financial resources, and for providing a particle beam from the CERN Proton Synchrotron. We thank Patrick Carrie, Louis-Philippe De Menezes, Jonathan Dumollard, Katja Ivanova, Francisco Josa, Ilia Krasin, Robert Kristic, Abdelmajid Laassiri, Osman Maksumov, Frank Malkemper, Benjamin Marichy, Herve Martinati, Sergey Vitaljevich Mizin, Robert Sitals, Albin Wasem and Mats Wilhelmsson for their contributions to the experiment.

Financial support. This research has been supported by the EC Seventh Framework Programme and European Union's Horizon 2020 programme, Marie Skłodowska Curie (grant nos. 316662 "CLOUD-TRAIN", no. 764991 "CLOUD-MOTION", MSCA-IF no. 656994 "nano-CAVa", MC-COFUND grant no. 600377, ERC projects no. 692891 "DAMOCLES", no. 638703 "COALA", no. 616075 "NANODYNAMITE", no. 335478 "QAPPA", no. 742206 "ATM-GP", no. 714621 "GASPARCON"), the German Federal Ministry of Education and Research (project nos. 01LK0902A, 01LK1222A, 01LK1601A), the Swiss National Science Foundation (projects no. 20020_152907, 200020_172602, 20FI20_159851, 200020_172602, 20FI20_172622), the Academy of Finland (Center of Excellence no. 307331, project nos. 299574, 296628, 306853, 304013), the Finnish Funding Agency for Technology and Innovation, the Väisälä Foundation, the Nessling Foundation, the Austrian Science Fund (FWF; project no. J3951N36, project no. P27295-N20), the Austrian research funding association (FFG, project no. 846050), the Portuguese Foundation for Science and Technology (project no. CERN/FP/116387/2010), the Swedish Research Council Formas (project number 2015-749), Vetenskapsrådet (grant 2011-5120), the Presidium of the Russian Academy of Sciences and Russian Foundation for Basic Research (grants 08-02-91006-CERN, 12-02-91522-CERN), the U.S. National Science Foundation (grants AGS1136479, AGS1447056,
AGS1439551, CHE1012293, AGS1649147, AGS1602086), the Wallace Research Foundation, the US Department of Energy (grant DE-SC0014469), the NERC GASSP project NE/J024252/1m, the Royal Society (Wolfson Merit Award), United Kingdom Natural Environment Research Council grant NE/K015966/1, Dreyfus Award EP-11-117, the French National Research Agency the Nord-Pas de Calais, European Funds for Regional Economic Development Labex-Cappa grant ANR-11-LABX-0005-01).

This open-access publication was funded by the Goethe University Frankfurt.

Review statement. This paper was edited by Yafang Cheng and reviewed by two anonymous referees.

\section{References}

Almeida, J., Schobesberger, S., Kürten, A., Ortega, I. K., Kupiainen-Määttä, O., Praplan, A. P., Adamov, A., Amorim, A., Bianchi, F., Breitenlechner, M., David, A., Dommen, J., Donahue, N. M., Downard, A., Dunne, E., Duplissy, J., Ehrhart, S., Flagan, R. C., Franchin, A., Guida, R., Hakala, J., Hansel, A., Heinritzi, M., Henschel, H., Jokinen, T., Junninen, H., Kajos, M., Kangasluoma, J., Keskinen, H., Kupc, A., Kurtén, T., Kvashin, A. N., Laaksonen, A., Lehtipalo, K., Leiminger, M., Leppä, J., Loukonen, V., Makhmutov, V., Mathot, S., McGrath, M. J., Nieminen, T., Olenius, T., Onnela, A., Petäjä, T., Riccobono, F., Riipinen, I., Rissanen, M., Rondo, L., Ruuskanen, T., Santos, F. D., Sarnela, N., Schallhart, S., Schnitzhofer, R., Seinfeld, J. H., Simon, M., Sipilä, M., Stozhkov, Y., Stratmann, F., Tomé, A., Tröstl, J., Tsagkogeorgas, G., Vaattovaara, P., Viisanen, Y., Virtanen, A., Vrtala, A., Wagner, P. E., Weingartner, E., Wex, H., Williamson, C., Wimmer, D., Ye, P., Yli-Juuti, T., Carslaw, K. S., Kulmala, M., Curtius, J., Baltensperger, U., Worsnop, D. R., Vehkamäki, H., and Kirkby, J.: Molecular understanding of sulphuric acid-amine particle nucleation in the atmosphere, Nature, 502, 359, https://doi.org/10.1038/nature12663, 2013.

Berndt, T., Herrmann, H., Sipilä, M., and Kulmala, M.: Highly Oxidized Second-Generation Products from the Gas-Phase Reaction of OH Radicals with Isoprene, J. Phys. Chem. A, 120, 10150 10159, https://doi.org/10.1021/acs.jpca.6b10987, 2016.

Berndt, T., Mentler, B., Scholz, W., Fischer, L., Herrmann, H., Kulmala, M., and Hansel, A.: Accretion Product Formation from Ozonolysis and $\mathrm{OH}$ Radical Reaction of $\alpha$-Pinene: Mechanistic Insight and the Influence of Isoprene and Ethylene, Environ. Sci. Technol., 52, 11069-11077, 2018a.

Berndt, T., Scholz, W., Mentler, B., Fischer, L., Herrmann, H., Kulmala, M., and Hansel, A.: Accretion Product Formation from Self- and Cross-Reactions of $\mathrm{RO}_{2}$ Radicals in the Atmosphere, Angewandte Chemie International Edition, 57, 3820 3824, https://doi.org/10.1002/anie.201710989, 2018 b.

Breitenlechner, M., Fischer, L., Hainer, M., Heinritzi, M., Curtius, J., and Hansel, A.: PTR3: An Instrument for Studying the Lifecycle of Reactive Organic Carbon in the Atmosphere, Anal. Chem., 89, 5824-5831, https://doi.org/10.1021/acs.analchem.6b05110, 2017. 
Budisulistiorini, S. H., Canagaratna, M. R., Croteau, P. L., Marth, W. J., Baumann, K., Edgerton, E. S., Shaw, S. L., Knipping, E. M., Worsnop, D. R., and Jayne, J. T.: Real-time continuous characterization of secondary organic aerosol derived from isoprene epoxydiols in downtown Atlanta, Georgia, using the Aerodyne Aerosol Chemical Speciation Monitor, Environ. Sci. Technol., 47, 5686-5694, 2013.

Carlton, A. G., Wiedinmyer, C., and Kroll, J. H.: A review of Secondary Organic Aerosol (SOA) formation from isoprene, Atmos. Chem. Phys., 9, 4987-5005, https://doi.org/10.5194/acp-9-49872009, 2009.

Dada, L., Paasonen, P., Nieminen, T., Buenrostro Mazon, S., Kontkanen, J., Peräkylä, O., Lehtipalo, K., Hussein, T., Petäjä, T., Kerminen, V.-M., Bäck, J., and Kulmala, M.: Long-term analysis of clear-sky new particle formation events and nonevents in Hyytiälä, Atmos. Chem. Phys., 17, 6227-6241, https://doi.org/10.5194/acp-17-6227-2017, 2017.

Duplissy, J., Merikanto, J., Franchin, A., Tsagkogeorgas, G., Kangasluoma, J., Wimmer, D., Vuollekoski, H., Schobesberger, S., Lehtipalo, K., Flagan, R. C., Brus, D., Donahue, N. M., Vehkamäki, H., Almeida, J., Amorim, A., Barmet, P., Bianchi, F., Breitenlechner, M., Dunne, E. M., Guida, R., Henschel, H., Junninen, H., Kirkby, J., Kürten, A., Kupc, A., Määttänen, A., Makhmutov, V., Mathot, S., Nieminen, T., Onnela, A., Praplan, A. P., Riccobono, F., Rondo, L., Steiner, G., Tome, A., Walther, H., Baltensperger, U., Carslaw, K. S., Dommen, J., Hansel, A., Petäjä, T., Sipilä, M., Stratmann, F., Vrtala, A., Wagner, P. E., Worsnop, D. R., Curtius, J., and Kulmala, M.: Effect of ions on sulfuric acid-water binary particle formation: 2 . Experimental data and comparison with QC-normalized classical nucleation theory, J. Geophys. Res.-Atmos., 121, 1752-1775, https://doi.org/10.1002/2015JD023539, 2016.

Ehn, M., Thornton, J. A., Kleist, E., Sipila, M., Junninen, H., Pullinen, I., Springer, M., Rubach, F., Tillmann, R., Lee, B., Lopez-Hilfiker, F., Andres, S., Acir, I.-H., Rissanen, M., Jokinen, T., Schobesberger, S., Kangasluoma, J., Kontkanen, J., Nieminen, T., Kurten, T., Nielsen, L. B., Jorgensen, S., Kjaergaard, H. G., Canagaratna, M., Maso, M. D., Berndt, T., Petaja, T., Wahner, A., Kerminen, V.-M., Kulmala, M., Worsnop, D. R., Wildt, J., and Mentel, T. F.: A large source of lowvolatility secondary organic aerosol, Nature, 506, 476-479, https://doi.org/10.1038/nature13032, 2014.

Frege, C., Ortega, I. K., Rissanen, M. P., Praplan, A. P., Steiner, G., Heinritzi, M., Ahonen, L., Amorim, A., Bernhammer, A.-K., Bianchi, F., Brilke, S., Breitenlechner, M., Dada, L., Dias, A., Duplissy, J., Ehrhart, S., El-Haddad, I., Fischer, L., Fuchs, C., Garmash, O., Gonin, M., Hansel, A., Hoyle, C. R., Jokinen, T., Junninen, H., Kirkby, J., Kürten, A., Lehtipalo, K., Leiminger, M., Mauldin, R. L., Molteni, U., Nichman, L., Petäjä, T., Sarnela, N., Schobesberger, S., Simon, M., Sipilä, M., Stolzenburg, D., Tomé, A., Vogel, A. L., Wagner, A. C., Wagner, R., Xiao, M., Yan, C., Ye, P., Curtius, J., Donahue, N. M., Flagan, R. C., Kulmala, M., Worsnop, D. R., Winkler, P. M., Dommen, J., and Baltensperger, U.: Influence of temperature on the molecular composition of ions and charged clusters during pure biogenic nucleation, Atmos. Chem. Phys., 18, 65-79, https://doi.org/10.5194/acp-18-65-2018, 2018.

Fuchs, H., Hofzumahaus, A., Rohrer, F., Bohn, B., Brauers, T., Dorn, H. P., Häseler, R., Holland, F., Kaminski, M., Li,
X., Lu, K., Nehr, S., Tillmann, R., Wegener, R., and Wahner, A.: Experimental evidence for efficient hydroxyl radical regeneration in isoprene oxidation, Nat. Geosci., 6, 1023, https://doi.org/10.1038/ngeo1964 2013.

Gordon, H., Sengupta, K., Rap, A., Duplissy, J., Frege, C., Williamson, C., Heinritzi, M., Simon, M., Yan, C., Almeida, J., Tröstl, J., Nieminen, T., Ortega, I. K., Wagner, R., Dunne, E. M., Adamov, A., Amorim, A., Bernhammer, A.-K., Bianchi, F., Breitenlechner, M., Brilke, S., Chen, X., Craven, J. S., Dias, A., Ehrhart, S., Fischer, L., Flagan, R. C., Franchin, A., Fuchs, C., Guida, R., Hakala, J., Hoyle, C. R., Jokinen, T., Junninen, H., Kangasluoma, J., Kim, J., Kirkby, J., Krapf, M., Kürten, A., Laaksonen, A., Lehtipalo, K., Makhmutov, V., Mathot, S., Molteni, U., Monks, S. A., Onnela, A., Peräkylä, O., Piel, F., Petäjä, T., Praplan, A. P., Pringle, K. J., Richards, N. A. D., Rissanen, M. P., Rondo, L., Sarnela, N., Schobesberger, S., Scott, C. E., Seinfeld, J. H., Sharma, S., Sipilä, M., Steiner, G., Stozhkov, Y., Stratmann, F., Tomé, A., Virtanen, A., Vogel, A. L., Wagner, A. C., Wagner, P. E., Weingartner, E., Wimmer, D., Winkler, P. M., Ye, P., Zhang, X., Hansel, A., Dommen, J., Donahue, N. M., Worsnop, D. R., Baltensperger, U., Kulmala, M., Curtius, J., and Carslaw, K. S.: Reduced anthropogenic aerosol radiative forcing caused by biogenic new particle formation, P. Natl. Acad. Sci. USA, 113, 12053-12058, 2016.

Greenberg, J. P., Guenther, A. B., Pétron, G., Wiedinmyer, C., Vega, O., Gatti, L. V., Tota, J., and Fisch, G.: Biogenic VOC emissions from forested Amazonian landscapes, Global Change Biol., 10, 651-662, 2004.

Guenther, A. B., Jiang, X., Heald, C. L., Sakulyanontvittaya, T., Duhl, T., Emmons, L. K., and Wang, X.: The Model of Emissions of Gases and Aerosols from Nature version 2.1 (MEGAN2.1): an extended and updated framework for modeling biogenic emissions, Geosci. Model Dev., 5, 1471-1492, https://doi.org/10.5194/gmd-5-1471-2012, 2012.

Jardine, A. B., Jardine, K. J., Fuentes, J. D., Martin, S. T., Martins, G., Durgante, F., Carneiro, V., Higuchi, N., Manzi, A. O., and Chambers, J. Q.: Highly reactive light-dependent monoterpenes in the Amazon, Geophys. Res. Lett., 42, 1576-1583, https://doi.org/10.1002/2014GL062573, 2015.

Kamens, R. M., Gery, M. W., Jeffries, H. E., Jackson, M., and Cole, E. I.: Ozone-isoprene reactions: Product formation and aerosol potential, Int. J. Chem. Kin., 14, 955-975, 1982.

Kanawade, V. P., Jobson, B. T., Guenther, A. B., Erupe, M. E., Pressley, S. N., Tripathi, S. N., and Lee, S.-H.: Isoprene suppression of new particle formation in a mixed deciduous forest, Atmos. Chem. Phys., 11, 6013-6027, https://doi.org/10.5194/acp11-6013-2011, 2011.

Kerminen, V.-M., Chen, X., Vakkari, V., Petäjä, T., Kulmala, M., and Bianchi, F.: Atmospheric new particle formation and growth: review of field observations, Environ. Res. Lett., 13, 1-38, 2018.

Kiendler-Scharr, A., Wildt, J., Maso, M. D., Hohaus, T., Kleist, E., Mentel, T. F., Tillmann, R., Uerlings, R., Schurr, U., and Wahner, A.: New particle formation in forests inhibited by isoprene emissions, Nature, 461, 381-384, 2009.

Kiendler-Scharr, A., Andres, S., Bachner, M., Behnke, K., Broch, S., Hofzumahaus, A., Holland, F., Kleist, E., Mentel, T. F., Rubach, F., Springer, M., Steitz, B., Tillmann, R., Wahner, A., Schnitzler, J.-P., and Wildt, J.: Isoprene in poplar emissions: effects on new particle formation and $\mathrm{OH}$ concentrations, At- 
mos. Chem. Phys., 12, 1021-1030, https://doi.org/10.5194/acp12-1021-2012, 2012.

Kirkby, J., Curtius, J., Almeida, J., Dunne, E., Duplissy, J., Ehrhart, S., Franchin, A., Gagné, S., Ickes, L., Kürten, A., Kupc, A., Metzger, A., Riccobono, F., Rondo, L., Schobesberger, S., Tsagkogeorgas, G., Wimmer, D., Amorim, A., Bianchi, F., Breitenlechner, M., David, A., Dommen, J., Downard, A., Ehn, M., Flagan, R. C., Haider, S., Hansel, A., Hauser, D., Jud, W., Junninen, H., Kreissl, F., Kvashin, A., Laaksonen, A., Lehtipalo, K., Lima, J., Lovejoy, E. R., Makhmutov, V., Mathot, S., Mikkilä, J., Minginette, P., Mogo, S., Nieminen, T., Onnela, A., Pereira, P., Petäjä, T., Schnitzhofer, R., Seinfeld, J. H., Sipilä, M., Stozhkov, Y., Stratmann, F., Tomé, A., Vanhanen, J., Viisanen, Y., Vrtala, A., Wagner, P. E., Walther, H., Weingartner, E., Wex, H., Winkler, P. M., Carslaw, K. S., Worsnop, D. R., Baltensperger, U., and Kulmala, M.: Role of sulphuric acid, ammonia and galactic cosmic rays in atmospheric aerosol nucleation, Nature, 476, 429, https://doi.org/10.1038/nature10343, 2011.

Kirkby, J., Duplissy, J., Sengupta, K., Frege, C., Gordon, H., Williamson, C., Heinritzi, M., Simon, M., Yan, C., Almeida, J., Tröstl, J., Nieminen, T., Ortega, I. K., Wagner, R., Adamov, A., Amorim, A., Bernhammer, A.-K., Bianchi, F., Breitenlechner, M., Brilke, S., Chen, X., Craven, J., Dias, A., Ehrhart, S., Flagan, R. C., Franchin, A., Fuchs, C., Guida, R., Hakala, J., Hoyle, C. R., Jokinen, T., Junninen, H., Kangasluoma, J., Kim, J., Krapf, M., Kürten, A., Laaksonen, A., Lehtipalo, K., Makhmutov, V., Mathot, S., Molteni, U., Onnela, A., Peräkylä, O., Piel, F., Petäjä, T., Praplan, A. P., Pringle, K., Rap, A., Richards, N. A. D., Riipinen, I., Rissanen, M. P., Rondo, L., Sarnela, N., Schobesberger, S., Scott, C. E., Seinfeld, J. H., Sipilä, M., Steiner, G., Stozhkov, Y., Stratmann, F., Tomé, A., Virtanen, A., Vogel, A. L., Wagner, A. C., Wagner, P. E., Weingartner, E., Wimmer, D., Winkler, P. M., Ye, P., Zhang, X., Hansel, A., Dommen, J., Donahue, N. M., Worsnop, D. R., Baltensperger, U., Kulmala, M., Carslaw, K. S., and Curtius, J.: Ion-induced nucleation of pure biogenic particles, Nature, 533, 521-526, https://doi.org/10.1038/nature17953, 2016.

Krechmer, J. E., Coggon, M. M., Massoli, P., Nguyen, T. B., Crounse, J. D., Hu, W., Day, D. A., Tyndall, G. S., Henze, D. K., Rivera-Rios, J. C., Nowak, J. B., Kimmel, J. R., Mauldin, R. L., Stark, H., Jayne, J. T., Sipilä, M., Junninen, H., Clair, J. M. S., Zhang, X., Feiner, P. A., Zhang, L., Miller, D. O., Brune, W. H., Keutsch, F. N., Wennberg, P. O., Seinfeld, J. H., Worsnop, D. R., Jimenez, J. L., and Canagaratna, M. R.: Formation of Low Volatility Organic Compounds and Secondary Organic Aerosol from Isoprene Hydroxyhydroperoxide Low-NO Oxidation, Environ. Sci. Technol., 49, 10330-10339, https://doi.org/10.1021/acs.est.5b02031, 2015.

Kürten, A., Rondo, L., Ehrhart, S., and Curtius, J.: Performance of a corona ion source for measurement of sulfuric acid by chemical ionization mass spectrometry, Atmos. Meas. Tech., 4, 437-443, https://doi.org/10.5194/amt-4-437-2011, 2011.

Kurtén, T., Tiusanen, K., Roldin, P., Rissanen, M., Luy, J.-N., Boy, M., Ehn, M., and Donahue, N.: $\alpha$-Pinene Autoxidation Products May Not Have Extremely Low Saturation Vapor Pressures Despite High O : C Ratios, J. Phys. Chem. A, 120, 2569-2582, https://doi.org/10.1021/acs.jpca.6b02196, 2016.

Lee, S.-H., Uin, J., Guenther, A. B., de Gouw, J. A., Yu, F., Nadykto, A. B., Herb, J., Ng, N. L., Koss, A., Brune, W.
H., Baumann, K., Kanawade, V. P., Keutsch, F. N., Nenes, A., Olsen, K., Goldstein, A., and Ouyang, Q.: Isoprene suppression of new particle formation: Potential mechanisms and implications, J. Geophys. Res.-Atmos., 121, 14621-14635, https://doi.org/10.1002/2016JD024844, 2016.

Lehtipalo, K., Yan, C., Dada, L., Bianchi, F., Xiao, M., Wagner, R., Stolzenburg, D., Ahonen, L. R., Amorim, A., Baccarini, A., Bauer, P. S., Baumgartner, B., Bergen, A., Bernhammer, A.-K., Breitenlechner, M., Brilke, S., Buchholz, A., Buenrostro Mazon, S., Chen, D., Chen, X., Dias, A., Dommen, J., Draper, D. C., Duplissy, J., Ehn, M., Finkenzeller, H., Fischer, L., Frege, C., Fuchs, C., Garmash, O., Gordon, H., Hakala, J., He, X., Heikkinen, L., Heinritzi, M., Helm, J. C., Hofbauer, V., Hoyle, C. R., Jokinen, T., Kangasluoma, J., Kerminen, V.-M., Kim, C., Kirkby, J., Kontkanen, J., Kürten, A., Lawler, M. J., Mai, H., Mathot, S., Mauldin III, R. L., Molteni, U., Nichman, L., Nie, W., Nieminen, T., Ojdanic, A., Onnela, A., Passananti, M., Petäjä, T., Piel, F., Pospisilova, V., Quéléver, L. L. J., Rissanen, M. P., Rose, C., Sarnela, N., Schallhart, S., Schuchmann, S., Sengupta, K., Simon, M., Sipilä, M., Tauber, C., Tomé, A., Tröstl, J., Väisänen, O., Vogel, A. L., Volkamer, R., Wagner, A. C., Wang, M., Weitz, L., Wimmer, D., Ye, P., Ylisirniö, A., Zha, Q., Carslaw, K. S., Curtius, J., Donahue, N. M., Flagan, R. C., Hansel, A., Riipinen, I., Virtanen, A., Winkler, P. M., Baltensperger, U., Kulmala, M., and Worsnop, D. R.: Multicomponent new particle formation from sulfuric acid, ammonia, and biogenic vapors, Sci. Adv., 4, eaau5363, https://doi.org/10.1126/sciadv.aau5363, 2018.

Lin, Y.-H., Zhang, Z., Docherty, K. S., Zhang, H., Budisulistiorini, S. H., Rubitschun, C. L., Shaw, S. L., Knipping, E. M., Edgerton, E. S., and Kleindienst, T. E.: Isoprene epoxydiols as precursors to secondary organic aerosol formation: acid-catalyzed reactive uptake studies with authentic compounds, Environ. Sci. Technol., 46, 250-258, 2011.

Malkin, T. L., Goddard, A., Heard, D. E., and Seakins, P. W.: Measurements of $\mathrm{OH}$ and $\mathrm{HO}_{2}$ yields from the gas phase ozonolysis of isoprene, Atmos. Chem. Phys., 10, 1441-1459, https://doi.org/10.5194/acp-10-1441-2010, 2010.

Martin, S. T., Andreae, M. O., Artaxo, P., Baumgardner, D., Chen, Q., Goldstein, A. H., Guenther, A., Heald, C. L., MayolBracero, O. L., McMurry, P. H., Pauliquevis, T., Pöschl, U., Prather, K. A., Roberts, G. C., Saleska, S. R., Silva Dias, M. A., Spracklen, D. V., Swietlicki, E., and Trebs, I.: Sources and properties of Amazonian aerosol particles, Rev. Geophys., 48, https://doi.org/10.1029/2008RG000280, 2010.

Martinez, M., Harder, H., Kubistin, D., Rudolf, M., Bozem, H., Eerdekens, G., Fischer, H., Klüpfel, T., Gurk, C., Königstedt, R., Parchatka, U., Schiller, C. L., Stickler, A., Williams, J., and Lelieveld, J.: Hydroxyl radicals in the tropical troposphere over the Suriname rainforest: airborne measurements, Atmos. Chem. Phys., 10, 3759-3773, https://doi.org/10.5194/acp10-3759-2010, 2010.

Massoli, P., Stark, H., Canagaratna, M. R., Krechmer, J. E., Xu, L., Ng, N. L., Mauldin III, R. L., Yan, C., Kimmel, J., and Misztal, P. K.: Ambient Measurements of Highly Oxidized GasPhase Molecules during the Southern Oxidant and Aerosol Study (SOAS) 2013, ACS Earth and Space Chemistry, 2, 653-672, 2018.

McFiggans, G., Mentel, T. F., Wildt, J., Pullinen, I., Kang, S., Kleist, E., Schmitt, S., Springer, M., Tillmann, R., Wu, C., Zhao, D., 
Hallquist, M., Faxon, C., Le Breton, M., Hallquist, Å. M., Simpson, D., Bergström, R., Jenkin, M. E., Ehn, M., Thornton, J. A., Alfarra, M. R., Bannan, T. J., Percival, C. J., Priestley, M., Topping, D., and Kiendler-Scharr, A.: Secondary organic aerosol reduced by mixture of atmospheric vapours, Nature, 565, 587-593, https://doi.org/10.1038/s41586-018-0871-y, 2019.

Molteni, U., Simon, M., Heinritzi, M., Hoyle, C. R., Bernhammer, A.-K., Bianchi, F., Breitenlechner, M., Brilke, S., Dias, A., Duplissy, J., Frege, C., Gordon, H., Heyn, C., Jokinen, T., Kürten, A., Lehtipalo, K.,Makhmutov, V., Petäjä, T., Pieber, S. M., Praplan, A. P., Schobesberger, S., Steiner, G., Stozhkov, Y., Tomé, A., Tröstl, J., Wagner, A. C., Wagner, R.,Williamson, C., Yan, C., Baltensperger, U., Curtius, J., Donahue, N. M., Hansel, A., Kirkby, J., Kulmala, M., Worsnop, D. R., and Dommen, J.: Formation of Highly Oxygenated Organic Molecules from $\alpha$-Pinene Ozonolysis: Chemical Characteristics, Mechanism, and Kinetic Model Development, ACS Earth and Space Chemistry, 3, 873883, 2019.

Paulot, F., Crounse, J. D., Kjaergaard, H. G., Kürten, A., Clair, J. M. S., Seinfeld, J. H., and Wennberg, P. O.: Unexpected epoxide formation in the gas-phase photooxidation of isoprene, Science, 325, 730-733, 2009.

Riccobono, F., Schobesberger, S., Scott, C. E., Dommen, J., Ortega, I. K., Rondo, L., Almeida, J., Amorim, A., Bianchi, F., Breitenlechner, M., David, A., Downard, A., Dunne, E. M., Duplissy, J., Ehrhart, S., Flagan, R. C., Franchin, A., Hansel, A., Junninen, H., Kajos, M., Keskinen, H., Kupc, A., Kürten, A., Kvashin, A. N., Laaksonen, A., Lehtipalo, K., Makhmutov, V., Mathot, S., Nieminen, T., Onnela, A., Petäjä, T., Praplan, A. P., Santos, F. D., Schallhart, S., Seinfeld, J. H., Sipilä, M., Spracklen, D. V., Stozhkov, Y., Stratmann, F., Tomé, A., Tsagkogeorgas, G., Vaattovaara, P., Viisanen, Y., Vrtala, A., Wagner, P. E., Weingartner, E., Wex, H., Wimmer, D., Carslaw, K. S., Curtius, J., Donahue, N. M., Kirkby, J., Kulmala, M., Worsnop, D. R., and Baltensperger, U.: Oxidation Products of Biogenic Emissions Contribute to Nucleation of Atmospheric Particles, Science, 344, 717-721, 2014.

Rissanen, M. P., Kurtén, T., Sipilä, M., Thornton, J. A., Kausiala, O., Garmash, O., Kjaergaard, H. G., Petäjä, T., Worsnop, D. R., Ehn, M., and Kulmala, M.: Effects of Chemical Complexity on the Autoxidation Mechanisms of Endocyclic Alkene Ozonolysis Products: From Methylcyclohexenes toward Understanding $\alpha$-Pinene, J. Phys. Chem. A, 119, 4633-4650, https://doi.org/10.1021/jp510966g, 2015.

Riva, M., Budisulistiorini, S. H., Zhang, Z., Gold, A., Thornton, J. A., Turpin, B. J., and Surratt, J. D.: Multiphase reactivity of gaseous hydroperoxide oligomers produced from isoprene ozonolysis in the presence of acidified aerosols, Atmos. Environ., 152, 314-322, 2017.

Sipilä, M., Sarnela, N., Jokinen, T., Henschel, H., Junninen, H., Kontkanen, J., Richters, S., Kangasluoma, J., Franchin, A., Peräkylä, O., Rissanen, M. P., Ehn, M., Vehkamäki, H., Kurten, T., Berndt, T., Petäjä, T., Worsnop, D., Ceburnis, D., Kerminen, V.-M., Kulmala, M., and O'Dowd, C.: Molecular-scale evidence of aerosol particle formation via sequential addition of $\mathrm{HIO}_{3}$, Nature, 537, 532-534, 2016.

Stolzenburg, D., Fischer, L., Vogel, A. L., Heinritzi, M., Schervish, M., Simon, M., Wagner, A. C., Dada, L., Ahonen, L. R., Amorim, A., Baccarini, A., Bauer, P. S., Baumgartner, B., Bergen, A.,
Bianchi, F., Breitenlechner, M., Brilke, S., Buenrostro Mazon, S., Chen, D., Dias, A., Draper, D. C., Duplissy, J., El Haddad, I., Finkenzeller, H., Frege, C., Fuchs, C., Garmash, O., Gordon, H., He, X., Helm, J., Hofbauer, V., Hoyle, C. R., Kim, C., Kirkby, J., Kontkanen, J., Kürten, A., Lampilahti, J., Lawler, M., Lehtipalo, K., Leiminger, M., Mai, H., Mathot, S., Mentler, B., Molteni, U., Nie, W., Nieminen, T., Nowak, J. B., Ojdanic, A., Onnela, A., Passananti, M., Petäjä, T., Quéléver, L. L. J., Rissanen, M. P., Sarnela, N., Schallhart, S., Tauber, C., Tomé, A., Wagner, R., Wang, M., Weitz, L., Wimmer, D., Xiao, M., Yan, C., Ye, P., Zha, Q., Baltensperger, U., Curtius, J., Dommen, J., Flagan, R. C., Kulmala, M., Smith, J. N., Worsnop, D. R., Hansel, A., Donahue, N. M., and Winkler, P. M.: Rapid growth of organic aerosol nanoparticles over a wide tropospheric temperature range, P. Natl. Acad. Sci. USA, 115, 9122-9127, 2018.

Surratt, J. D., Chan, A. W., Eddingsaas, N. C., Chan, M., Loza, C. L., Kwan, A. J., Hersey, S. P., Flagan, R. C., Wennberg, P. O., and Seinfeld, J. H.: Reactive intermediates revealed in secondary organic aerosol formation from isoprene, P. Natl. Acad. Sci. USA, 107, 6640-6645, 2010.

Taraborrelli, D., Lawrence, M. G., Crowley, J. N., Dillon, T. J., Gromov, S., Groß, C. B. M., Vereecken, L., and Lelieveld, J.: Hydroxyl radical buffered by isoprene oxidation over tropical forests, Nat. Geosci., 5, 190, https://doi.org/10.1038/ngeo1405 2012.

Teng, A. P., Crounse, J. D., and Wennberg, P. O.: Isoprene Peroxy Radical Dynamics, J. Am. Chem. Soc., 139, 5367-5377, https://doi.org/10.1021/jacs.6b12838, 2017.

Tröstl, J., Chuang, W. K., Gordon, H., Heinritzi, M., Yan, C., Molteni, U., Ahlm, L., Frege, C., Bianchi, F., Wagner, R., Simon, M., Lehtipalo, K., Williamson, C., Craven, J. S., Duplissy, J., Adamov, A., Almeida, J., Bernhammer, A.-K., Breitenlechner, M., Brilke, S., Dias, A., Ehrhart, S., Flagan, R. C., Franchin, A., Fuchs, C., Guida, R., Gysel, M., Hansel, A., Hoyle, C. R., Jokinen, T., Junninen, H., Kangasluoma, J., Keskinen, H., Kim, J., Krapf, M., Kürten, A., Laaksonen, A., Lawler, M., Leiminger, M., Mathot, S., Möhler, O., Nieminen, T., Onnela, A., Petäjä, T., Piel, F. M., Miettinen, P., Rissanen, M. P., Rondo, L., Sarnela, N., Schobesberger, S., Sengupta, K., Sipilä, M., Smith, J. N., Steiner, G., Tomè, A., Virtanen, A., Wagner, A. C., Weingartner, E., Wimmer, D., Winkler, P. M., Ye, P., Carslaw, K. S., Curtius, J., Dommen, J., Kirkby, J., Kulmala, M., Riipinen, I., Worsnop, D. R., Donahue, N. M., and Baltensperger, U.: The role of low-volatility organic compounds in initial particle growth in the atmosphere, Nature, 533, 527, https://doi.org/10.1038/nature18271, 2016.

Varanda Rizzo, L., Roldin, P., Brito, J., Backman, J., Swietlicki, E., Krejci, R., Tunved, P., Petäjä, T., Kulmala, M., and Artaxo, P.: Multi-year statistical and modeling analysis of submicrometer aerosol number size distributions at a rain forest site in Amazonia, Atmos. Chem. Phys., 18, 10255-10274, https://doi.org/10.5194/acp-18-10255-2018, 2018.

Wildt, J., Mentel, T. F., Kiendler-Scharr, A., Hoffmann, T., Andres, S., Ehn, M., Kleist, E., Müsgen, P., Rohrer, F., Rudich, Y., Springer, M., Tillmann, R., and Wahner, A.: Suppression of new particle formation from monoterpene oxidation by $\mathrm{NO}_{x}$, Atmos. Chem. Phys., 14, 2789-2804, https://doi.org/10.5194/acp14-2789-2014, 2014.

Wimmer, D., Buenrostro Mazon, S., Manninen, H. E., Kangasluoma, J., Franchin, A., Nieminen, T., Backman, J., Wang, J., 
Kuang, C., Krejci, R., Brito, J., Goncalves Morais, F., Martin, S. T., Artaxo, P., Kulmala, M., Kerminen, V.-M., and Petäjä, T.: Ground-based observation of clusters and nucleation-mode particles in the Amazon, Atmos. Chem. Phys., 18, 13245-13264, https://doi.org/10.5194/acp-18-13245-2018, 2018.

Yáñez-Serrano, A. M., Nölscher, A. C., Bourtsoukidis, E., Gomes Alves, E., Ganzeveld, L., Bonn, B., Wolff, S., Sa, M., Yamasoe, M., Williams, J., Andreae, M. O., and Kesselmeier, J.: Monoterpene chemical speciation in a tropical rainforest:variation with season, height, and time of dayat the Amazon Tall Tower Observatory (ATTO), Atmos. Chem. Phys., 18, 3403-3418, https://doi.org/10.5194/acp-18-3403-2018, 2018.
Yu, H., Ortega, J., Smith, J. N., Guenther, A. B., Kanawade, V. P., You, Y., Liu, Y., Hosman, K., Karl, T., Seco, R., Geron, C., Pallardy, S. G., Gu, L., Mikkilä, J., and Lee, S.-H.: New Particle Formation and Growth in an Isoprene-Dominated Ozark Forest: From Sub-5 nm to CCN-Active Sizes, Aerosol Sci. Technol., 48, 1285-1298, https://doi.org/10.1080/02786826.2014.984801, 2014. 